\title{
Correction to: Genetic and ecological consequences of recent habitat fragmentation in a narrow endemic plant species within an urban context
}

\author{
Nicola Delnevo ${ }^{1}$ (D) Andrea Piotti ${ }^{2}$ (D) $\cdot$ Michele Carbognani $^{3}$ (D) Eddie J. van Etten ${ }^{1}$ (D) \\ William D. Stock ${ }^{1}$ (D) . David L. Field ${ }^{1}$ (D) Margaret Byrne ${ }^{4}$ (D)
}

Published online: 13 September 2021

(c) Springer Nature B.V. 2021

\section{Correction to: Biodiversity and Conservation https://doi.org/10.1007/s10531-021-02256-x}

The article 'Genetic and ecological consequences of recent habitat fragmentation in a narrow endemic plant species within an urban context', written by Nicola Delnevo, Andrea Piotti, Michele Carbognani, Eddie J. van Etten, William D. Stock, David L. Field and Margaret Byrne was originally published electronically on the publisher's internet portal (currently SpringerLink) on 27 July 2021 without open access.

With the author(s)' decision to opt for Open Choice, the copyright of the article changed on 31 August 2021 to (C) The Author(s) 2021 and the article is forthwith distributed under the terms of copyright. The original article has been corrected.

Open Access This article is licensed under a Creative Commons Attribution 4.0 International License, which permits use, sharing, adaptation, distribution and reproduction in any medium or format, as long as you give appropriate credit to the original author(s) and the source, provide a link to the Creative Commons licence, and indicate if changes were made. The images or other third party material in this article are included in the article's Creative Commons licence, unless indicated otherwise in a credit line to the material. If material is not included in the article's Creative Commons licence and your intended use is not permitted by statutory regulation or exceeds the permitted use, you will need to obtain permission directly from the copyright holder. To view a copy of this licence, visit http://creativecommons.org/licenses/by/4.0/.

The original article can be found online at https://doi.org/10.1007/s10531-021-02256-x.

Nicola Delnevo

n.delnevo@ecu.edu.au

1 Centre for Ecosystem Management, Edith Cowan University, 270 Joondalup Drive, Joondalup, WA 6027, Australia

2 Institute of Biosciences and BioResources (IBBR), National Research Council (CNR), 50019 Sesto Fiorentino, Firenze, Italy

3 Department of Chemistry, Life Sciences, and Environmental Sustainability, University of Parma, Parco Area delle Scienze 11/A, 43124 Parma, Italy

4 Biodiversity and Conservation Science, Department of Biodiversity, Conservation, and Attractions, Bentley Delivery Centre, Locked Bag 104, Bentley, WA 6983, Australia 
Publisher's Note Springer Nature remains neutral with regard to jurisdictional claims in published maps and institutional affiliations. 